\title{
EVALUATION OF SOME PLANT EXTRACTS, DIFFERENT CULTIVARS AND FUNGICIDES IN CONTROLLING TOMATO WILT DISEASE
}

\author{
M. Ammar, H. Awad and M. Gaballa \\ Plant Pathology, Fac. of Agric., Menoufia University. \\ Received: Jun. 7, 2020 \\ Accepted: Aug. 4, 2020
}

\begin{abstract}
Tomato Fusarial wilt is very dangerous diease which affect the plant growth and yield production. This work was carried out to achieve some alternative control methods instead of using fungicides in order to control this disease Fusarium oxysporum f. sp. lycopersici was isolated from six Egyptian governorates ${ }^{i e}$ (Minufiya, Alexandria, Aswan, Behera, Sharqiya and Matrouh) with different frequency (25 - 42); respectively at Alexandria and Minufiya. Pathoganicity test experiments showed that the most aggressive isolates were No 7 and No.9, obtained from Behera and Minufiya respectively. While the least aggressive ones were isolate (1) and (2) obtained from Alexandria and Aswan. Laboratory experiments cleared that the best plant water extract for reducing the fungal growth were camphor and nerium and the least effective ones were aloe vera and pricklypear. In general, increasing the concentration of any tested plant extract reduced the fungal growth. All tested fungicides reduced the growth of both isolates (7\&9) compared than control; significantly. Increasing the Concentration of any fungicide, significantly reduced the fungal growth. Brivio cultivar was the least susceptible one to wilt disease caused by isolate (9) of Fusarium oxysporum f.sp. lycopersici under greenhouse conditions. While Elissa cultivar was the most susceptible one. Aloe vera and nerium plant water extract were most effective ones for improving growth and reducing wilt disease symptoms increasing the concentration of any tested plant extract (5-10-20\%) showed more positive results, both in plant growth and disease reduction. Prevecure energy and Tachigaren fungicides gave the best results in reducing the wilt disease parameters and improving Elissa tomato cultivar growth.
\end{abstract}

Key words: Plant water extracts, fusarium oxysporum, mint, camphor, werium tachigaren, prevecure energy, trichoderma .

\section{INTRODUCTION}

Vegetable crops are considered a major source of essential nutrients such as vitamins, minerals, carbohydrates, antioxidants and anti-carcinogenic substances, which are important human nutrition and health (Joseph, 1994).

Tomato (Lycopersicon esculentum L.) is considered one of the major vegetable summer crops in commercial fields in Egypt. It can be grown in different seasons throughout the year in both, open filed and greenhouse conditions. Tomato is attacked by several fungal diseases during different growth stages causing considerable losses in fruit yield. These diseases are early blight, late blight, Fusarium wilt, Verticillium wilt, white mold and anthracnose. (Datnoff et al., 1993).

Soil borne diseases are economically very important and responsible for severe losses in fruit yield due to diseases infection. Fusarium spp., Verticillium spp., Alternaria solani, and Phytophthora infestans, are the most common pathogens on tomato plants causing damping-off, root rot and wilt of tomato, they were frequently isolated from the 
infected samples of tomato (Angelo, 1995).

The Fusarium Vascular wilt (fusarium wilt) of Tamato caused by Fusarium oxysporum f.sp lycopersici recognized as one of the most devastating disease and major yield limiting factor in tomato worldwide (Chehri K., 2016, Prasad et al.; 2016 and Manikandan et al.; 2018).

Currently, there is a worldwide trend to explore new alternatives to synthetic fungicides in order to minimize the risks associated with development of population insensitive to these chemical compounds and also comply with food safety standards.

Furthermore, the use of some synthetic chemicals to control fungal diseases is restricted due to their high toxicity long degradation period and environmental pollution. The use of natural compounds as plant extracts may be an alternative to fungicides to control plant pathogens (Tsair -Bor and ShangTzen 2008).

Therefore, this present study was aimed to isolate Fusarium oxysporum f.sp. lycopersici the causal organism of tomato wilt and investigated the effect of some plant extracts and chemical fungicides in laboratory and greenhouse conditions.

\section{MATERIALS AND METHODS Isolation of the causal organisms}

Samples of naturally infected tomato plants at various developmental stages, showing different degrees of wilt infection symptoms, were collected from different tomato growing areas in Egypt. These growing areas represented by six governorates i. e. Alexandria, Aswan, Behera, Matrouh, Meniofia and Sharqiya. Survey was carried out during two successive growing seasons of 2017 and 2018. The infected roots which had vascular brown discoloration were cut into small pieces, washed thoroughly with running water, to remove the adhering soil particles. They were surface sterilized by immersing them in $0.25 \%$ sodium hypochlorite solution for 4 minutes. The samples were washed several times in sterilized distilled water and blotted between sterilized filtered papers. Then they were transferred onto Potato Dextrose Agar medium (PDA) containing Penicillin (50 units / ml.), 20 ppm Tetramycin and $40 \mathrm{ppm}$ Streptomycin sulfate to avoid bacterial contamination. The inoculated plates were incubated at $25^{\circ} \mathrm{C}$ for $6-7$ days and examined daily for the occurrence of fungal growth. The developed fungal colonies were microscopally examined and purified to isolata single colonies for further studies.

\section{Identification of the isolated fungi:}

The obtained fungi were identified at Agricultural Botany Department, Faculty of Agriculture, Minufiya University, using the morphological and microscopical characteristics, either to generic or species level according to the description of Gilman (1957), Barnett (1960), Booth (1971) and Barnett and Hunter (1998). The identification was confirmed by the Taxonomy Mycological Research Department, Plant Pathology institutes, Agricultural Research center (ARC), Giza, Egypt. Identification of the isolated fungi was done using the characters of Fusarium oxysporum according to Nelson et al., (1983), which were as follows:

- Microconidia: Abundant, generally single - celled, oral or kidney shaped and produced only in false heads.

- Macroconidia: Abundant, only slight sickle - shaped, thin walled and delicate, with an attenulated apical cell and a foot shaped basal cell.

- Conidiophores: UN - branched and branched monophialides. The monophialides bearing microconidia are sharp when compared to those produced by Fusarium solani and $E$. moniliforme. 
- Colony morphology: On PDA, growth is rapid and white aerial mycelium may become tinged with purple or be submerged by the blue color and sclerotia when they are abundant, espically at the base of the slant, or by the cream to tan or orange sporodochia when these are abundant. Discrete erumpent orange sporodochia are present in some strains. The under surface may be colorless to dark or dark purple, and these colors may be visible through the mycelium when viewed from above.

\section{Identification of Fusarium oxysporum f. sp. lycopersici:}

The mycelia of Fusarium oxysporum $f$. sp. lycopersici (Sacc.) W. C. Snyder and H. $\mathrm{N}$. Hans are delicate white to pink, often with purple tinge, and are sparse to abundant. The fungus produces three types of spores: microconidia, macroconidia, and chlamydospores. Microconidia are borne on simple phialides arising laterally and are abundant, oval - ellipsoid, straight to curved, 5 - $12 \times 2.2$ - 3. $5 \mathrm{um}$, and nonseptate. Macroconidia, sparse to abundant, are borne on branched conidiophores or on the surface of sporodochia and are thin walled, three - to five - septate, fusoid - subulate and pointed at both ends, have pedicellate base. Three - septate conidia measure 27 - 46 x 3 - 5 um while five - septate conidia measure 35 - $60 \times 3-5 \mathrm{~m}$. Three - septate spores are more common. Chlamydospores, both smooth and rough walled, are shundant and form terminally or on an intercalary basis. They are generally solitary, but occasionally form in pairs or chains. No perfect stage is known.

\section{Pathogenicity test:}

Ten isolates of Fusarium oxysporum $\mathrm{f}$ sp. Lycopersici; were isolated in high frequencies and tested under greenhouse conditions for their pathogenic potentialities using a susceptible tomato cultivar Elissaa. Pots ( $25 \mathrm{~cm}$ in diameter ) were sterilized by immersing in $5 \%$ formalin solution for 15 minutes and covered overnight with plastic sheets then left to dry in open air, soil sterilization was carried out by the same agent at the rate of 1 liter / 1 field soil, then covered by polyethylene sheet for one week for complete sterilization. Treated soil was left for 2 weeks while mixed continuously to ensure complete evaporation of formalin. The tested isolates were, individually, grown in plates $(9 \mathrm{~cm}$ in diameter) containing $20 \mathrm{ml}$ of PDA medium. All the dishes were incubated at $25^{\circ} \mathrm{C}$ for 10 days. The growing fungi were inoculated individually in bags of polyethylene containing sterilized sand barely medium ( $25 \mathrm{~g}$ sand and $75 \mathrm{~g}$ barely grains) and enough water to cover the mixture, followed by autoclaving at $1.5 \mathrm{~kg}$ $1 \mathrm{~cm}$ for $\mathbf{3 0}$ minutes. The bags contents of the fungal cultures were thoroughly mixed with autoclaved soil at the rate of $3 \%$ of soil weight, then filled in previously sterilized pots. The infested soil was moistered and mixed thoroughly every other day for one week. Soil mixed with sterilized sand - barely medium, at the same rate, was used as control.

\section{Varietal resistance:}

From the obtained results of pathogenicity test, the most virulent tow isolates of Fusarium oxysporum f. sp. Lycopersici (isolates No. 7 and 9), were selected for this experiment. The sand / cornmeal / wheat bran medium (1: 2: 2v / v) was backed in polyethylene bags, watered and autoclaved for $\mathbf{3 0}$ minutes at $121^{\circ} \mathrm{C}$. Then it was inoculated with equal disks of 7 days old mycelia growth of the above mentioned selected isolates. The bags were incubated for 15 days at $25{ }^{\circ} \mathrm{C}$. Four tomato genotypes, lines and hybrids; i. Brivio, 023, 010 and Elissaa; 
were evaluated against the most virulent isolates under greenhouse conditions.

Inoculum was added to the field soil at the rate of $3 \%$ of soil weight in each pot as previously described.

\section{Cultivation in infested soil:}

Tomato (Lycopersicum esculentum); Elissaa cultivar was used in this experiment. One month old of tomato seedlings were transplanted in pots, free of fungal infection (Sterilized seeds were sown in sterilized soil) at the rate of 3 seedlings / pot. A set of four pots were used for each isolate as replicates, as well as, for the uninfected soil as control treatment. At the mature stage (90 days old) the plants were carefully pulled out from the pots after being flooded with water in order to have all root system undamaged. Roots showing discoloration of vessels in the longitudinal sections were considered diseased (Ibrahim and Abdul - Rehim, 1965). Plant showing typical wilt symptoms were used for isolation of the causal fungi. Disease assessment for the percentage of pre emergence damping - off was recorded after 30 days from sowing date. Percentage of the post - emergence damping - off and wilt were calculated during 60 and 90 days old of the tomato plant respectively, according to the external and internal disease symptoms.

\section{Plant extracts:}

Because a lot of problems threaten to limit the continued use of fungicides; these experiments conducted to use environmentally safe alternative methods of fungal control as aqueous extract of many allelopathic plants. All powder plants of this study were collected and identified at the Herbarium of the Dept. of Medical plants, Fac. of Pharmaceutical Sciences and Industries, Future University, New Cairo. Aqueous extracts of plant samples were prepared according to Mutwally et al., 2010. Six plant materials were used for preparation of extracts, i. e., African milk bush, Aloe vera, Camphor, Mint, Nerium and prickly pear Table (1).

\section{Fungicides:}

This study was carried out using different fungicides to evalulate their effect on wilt pathogen; Fusarium oxysporum f. sp. Lycopersici; in vitro and in vivo under greenhouse conditions. These fungicides are presented in Table (2). In vitro experiments tested three concentrations i.e., half of recommended dose, recommended dose and doubles of recommended were used for each fungicide. The fungicides were added to Czapek's medium before solidifying and rotated gently to ensure an even distribution of fungicide. Equal ounts of medium were poured in Petri dishes. Two perpendicular diameters were drown on the bottom of the dish. A disk ( $5 \mathrm{~mm}$ in diameter ) from 7 days old fungus culture on Czapek' $s$ medium was transferred to the center of the dish. Three replicates were used for each concentration. The dishes were incubated at $28^{\circ} \mathrm{C}$ and the two diameters of every dish were measured daily until full growth was noticed in the control. The average diameter and length was calculated. In vivo experiments tested the effect of some fungicides on wilt incidence was studied. Pot experiment was carried out in the Plant Pathology Department greenhouse, Faculty of Agriculture, Minufiya University the tested fungicides, i.e. and Topsin - M were Tashgareen, Carbendazim, Previcur energy, Rizolex - T applied by applying the tested fungicides individually to the plants in polyethylene bags. The treated tomato CV. Elissa was sown in pots (25 $\mathrm{cm}$ in diameter) containing $5 \mathrm{~kg}$ of artificially infested soil with the most virulent isolates of wilt pathogen (isolates No. 9). Another set of pots containing infested and non - infested soils, were sown with untreated plans and used as control. 
Table (1): Common, Arabic, scientific names and used parts of different types of plants used for preparing water extracts.

\begin{tabular}{|c|c|c|c|}
\hline Arabic name & Common name & scientific name & Used Part \\
\hline كافور & Camphor & Cinnamomum camphora & leaves \\
\hline دفلة & Nerium & Nerium oleander & leaves \\
\hline صبار جوافة & Mint & Mentha villosa & Stem and leaves \\
\hline دبن شوكى & African milk bush & Euphorbia umbellata & Leaves \\
\hline صبار & Aloe vera & Aloe barbadensis & Stem \\
\hline
\end{tabular}

Table (2): The fungicides tested for controlling tomato wilt disease:

\begin{tabular}{|c|c|c|c|c|}
\hline Trade name & Active ingredient & Dose & Manufacturer & Country \\
\hline $\begin{array}{l}\text { Previcur energy } \\
\text { SL \%84 }\end{array}$ & $\begin{array}{c}\text { fosetyl-aluminium } 31 \% \\
\text { propamocarb } \\
\text { hydrochloride } \% 53\end{array}$ & $3 \mathrm{cc} / 1 \mathrm{~L}$ & Bayer & Germany \\
\hline $\begin{array}{l}\text { Tachigaren } \\
\text { 30\% SL }\end{array}$ & hymexazole $\% 30$ & $1 \mathrm{cc} / 1 \mathrm{~L}$ & $\begin{array}{c}\text { mitsu } \\
\text { chemicals }\end{array}$ & Japan \\
\hline $\begin{array}{l}\text { سندو 50 } \\
\text { WP }\end{array}$ & Carbendazim $50 \%$ & - l 75 & $\begin{array}{c}\text { Anhui } \\
\text { Guangxin } \\
\text { Agrochemical }\end{array}$ & China \\
\hline $\begin{array}{l}\text { توبسين إم \% } \\
\text { WP } 70\end{array}$ & $\begin{array}{l}\text { Thiophanate- } \\
70 \text { methyl } \\
\% 70 \\
\end{array}$ & - 1 & $\begin{array}{l}\text { Nippon Soda } \\
\text { Co., LTD }\end{array}$ & japan \\
\hline $\begin{array}{l}\text { Rizolex - T } \\
50 \% \mathrm{Wp}\end{array}$ & $\begin{array}{c}\text { telclofos - methyl } 20 \% \text { thiram } \\
30 \%\end{array}$ & $\begin{array}{c}3 \mathrm{~g} / \\
1 \mathrm{~kg} \text { seeds }\end{array}$ & sumitomo & japan \\
\hline
\end{tabular}

\section{Statistical analysis:}

All data obtained were subjected to the proper statistical analysis for each experiment using the Costat (2004) statistical software. Comparisons were made following Duncan's LSD (0. 05).

\section{RESULTS}

Survey of the pathogenic and beneficial fungal isolates:

Results present in Table (3) indicate that Fusarium oxysporum $f$. $s p$. lycopersici was the most prevalent fungus isolated from 10 samples collected from different districts as sampled various 6 governorates (34.95\%). El-sadat district followed by El-salhya one gave the most percentage of $F$. oxysporum isolates. However, the least frequency of this fungus was obtained from El-bangar district, Alexandria governorate $(25 \%)$. Of 103 samples; F. solani was (4.56\%) Rhizoctonia solani was $(10.67 \%)$ and Alternaria solani showed (15.53\%) isolates. On the other hand, Trichoderma harziaum and T.veridi were recovered from the healthy plant samples and assempled $6.79 \%$ per each fungus. Trichoderma veridi was highly isolated from Sharqiya governorate; Slhya district. While T.harziaum was more prevalent at Sadat city; Menoufia governorate (14.28\%). 
Table (3): The isolated fungi from diseased and healthy tomato plants collected from six Egyptian governorates.

\begin{tabular}{|c|c|c|c|c|c|c|c|c|}
\hline \multirow[b]{2}{*}{ governorate } & \multirow[b]{2}{*}{ District } & \multirow[b]{2}{*}{$\begin{array}{c}\text { No. of } \\
\text { sampeles }\end{array}$} & \multicolumn{6}{|c|}{ Frequency of isolated fungus (\%) } \\
\hline & & & $\begin{array}{l}\text { Fusarium } \\
\text { oxysporum }\end{array}$ & $\begin{array}{c}\text { Fusarium } \\
\text { solani }\end{array}$ & $\begin{array}{c}\text { Rhizoctonia } \\
\text { solani }\end{array}$ & $\begin{array}{c}\text { Alternaria } \\
\text { solani }\end{array}$ & $\begin{array}{c}\text { Trichoderma } \\
\text { harziaum }\end{array}$ & $\begin{array}{c}\text { Trichoderma } \\
\text { viride }\end{array}$ \\
\hline Alexandria & $\begin{array}{c}\text { EI } \\
\text { Bangar }\end{array}$ & 20 & 25 & 15 & 10 & 15 & 10 & 5 \\
\hline Aswan & $\begin{array}{c}\text { Garf } \\
\text { hessien }\end{array}$ & 21 & 33.33 & 9.52 & 19.04 & 14.28 & 4.76 & 9.52 \\
\hline Behera & $\begin{array}{c}\text { Wadi } \\
\text { Elnatron }\end{array}$ & 15 & 40 & 13.33 & 6.66 & 20 & 6.66 & 0 \\
\hline Matrouh & $\begin{array}{c}\text { Al } \\
\text { Hamam }\end{array}$ & 21 & 33.33 & 19.04 & 9.52 & 14.28 & 4.76 & 4.76 \\
\hline Minufiya & $\begin{array}{l}\text { Sadat } \\
\text { city }\end{array}$ & 14 & 42.85 & 14.28 & 7.14 & 21.42 & 14.28 & 0 \\
\hline Sharqiya & Salhya & 12 & 41.66 & 16.66 & 8.33 & 8.33 & 0 & 16.66 \\
\hline Total & & 103 & 34.95 & 14.56 & 10.67 & 15.53 & 6.79 & 6.79 \\
\hline
\end{tabular}

\section{Pathogenicity test:}

Ten Fusarium oxysporum f. sp. Lycopersici isolates were tested for their pathogenicity to tomato cultivar under greenhouse condition. Results shown in Table (4) clear that the isolates No 9,7 and 3 were $91.33,83.33$ and $83.33 \%$ respectively. However, completely dead plants were achieved after 28 days from transplanting in the soil infested with either isolate 7 and / or Isolate 9. In the meantime, isolates 1,6 and 8 were the least aggressive ones, where the survived plants were $(16.67 \%)$ up to 28 days from showing. Control plants seemed healthy all the time of the experiment and survived plants were $100 \%$.

\section{Cultivar resistance:}

Four tomato cultivars i.e. 010, 023, Brivio and Elissa were tested for their susceptibility to isolate (9) of Fusarium oxysporun f.sp. Lycopersici. Results present in Table (5) clear that Brivio cultivar was the least susceptible one followed by 010 cultivar. After 80 days from sowing in the infested soil; survival plants recorded 53.33 and $46.66 \%$; respectively for Brivio and 010 cus. Elissa cultivar was the highly susceptible one where $3.33 \%$ only of the plants still a life up to 80 days from transplanting in the infested soil. Tomato cultivar 023 was modernly susceptible $(23.33 \%$ survival plants after 80 days from sowing).

\section{Laboratory experiments:}

Effect of plant water extracts on the pathogens growth:

The concentration of 5,10 and $20 \%$ of different extracts of medicinal plants were tested against two isolates of F.oxysporum lycopersici (7 and 9 ) in petri dishes Table (6). The obtained results clear that all tested plant extracts at all concentration reduced the average growth of both isolates than control; significantly. It was also noticed that 
increasing the concentration of any tested extract had more efficiency in reducing the fungal growth. Significant different concentration. Nerium extract was the most effective one in reduction the fungal growth, followed by camphor one. Reduction of the growth than control recorded $60 \%$ and $58.89 \%$ for isolates 7 and 9 respectively; at the concentration of
$20 \%$ of nerium. In the same respect, these were 50.17 and $48.89 \%$ when camphor extract $(20 \%)$ was applied. In the meantime the least effective extract were aloe vera and pirckly pear. They reduced the growth of isolate (7) by 21.08 and $26.08 \%$ respectively for aloe vera and prickly pear (5\% concentration).

Table (4): Pathogenicity test of 10 Fusarium oxysporum f.sp. lycopersici isolates on tomato plants cv. Elissa under greenhouse conditions.

\begin{tabular}{|c|c|c|c|c|c|c|c|}
\hline \multirow{2}{*}{$\begin{array}{c}\text { Isolate } \\
\text { No }\end{array}$} & governorate & \multicolumn{2}{|c|}{$\begin{array}{c}\text { Plants with Initial } \\
\text { symptoms }\end{array}$} & \multicolumn{2}{|c|}{ Collapsed Plants } & \multicolumn{2}{c|}{ Survival Plant } \\
\cline { 3 - 8 } & & No & $\%$ & No & $\%$ & No & $\%$ \\
\hline$F_{1}$ & Alexandria & 3 & 25 & 7 & 55.33 & 2 & 16.66 \\
\hline$F_{2}$ & Aswan & 2 & 16.66 & 7 & 55.33 & 3 & 25 \\
\hline$F_{3}$ & Aswan & 0 & 0 & 10 & 83.33 & 2 & 16.66 \\
\hline$F_{4}$ & Matrouh & 2 & 16.66 & 9 & 75 & 1 & 8.33 \\
\hline$F_{5}$ & Sharqiya & 1 & 8.33 & 8 & 66.66 & 3 & 25 \\
\hline$F_{6}$ & Sharqiya & 3 & 25 & 7 & 55.33 & 2 & 16.67 \\
\hline$F_{7}$ & Behera & 2 & 19.66 & 10 & 83.33 & 0 & 0 \\
\hline$F_{8}$ & Behera & 1 & 8.33 & 9 & 75 & 2 & 16.67 \\
\hline$F_{9}$ & Minufiya & 1 & 8.33 & 11 & 91.66 & 0 & 0 \\
\hline$F_{10}$ & Minufiya & 2 & 16.67 & 9 & 75 & 1 & 8.33 \\
\hline & Control & 0 & 0 & 0 & 0 & 12 & 100 \\
\hline
\end{tabular}

Table (5): Tomato cultivar resistance to Fusarium oxysporun f.sp. lycopersici. Under greenhouse conditions.

\begin{tabular}{|c|c|c|c|c|c|c|c|c|c|}
\hline \multirow{3}{*}{ Cultivar } & \multirow{3}{*}{$\begin{array}{l}\text { No. of } \\
\text { plants }\end{array}$} & \multicolumn{6}{|c|}{ Diseased plants } & \multirow{2}{*}{\multicolumn{2}{|c|}{$\begin{array}{c}\text { Survival } \\
\text { Plants }\end{array}$}} \\
\hline & & \multicolumn{2}{|c|}{$\begin{array}{c}\text { Plants with } \\
\text { initial } \\
\text { symptoms }\end{array}$} & \multicolumn{2}{|c|}{$\begin{array}{l}\text { Collapsed } \\
\text { plants }\end{array}$} & \multicolumn{2}{|c|}{ Total } & & \\
\hline & & No & $\%$ & No & $\%$ & No & $\%$ & No & $\%$ \\
\hline 010 & 30 & 3 & 10 & 13 & 43.33 & 16 & 53.33 & 14 & 46.66 \\
\hline 023 & 30 & 3 & 10 & 20 & 66.66 & 23 & 76.66 & 7 & 23.33 \\
\hline Brivio & 30 & 4 & 13 & 11 & 36.66 & 14 & 46.66 & 16 & 53.33 \\
\hline
\end{tabular}


M. Ammar, et al.,

Table (6): Effect of different concentrations of some plant extracts on the growth of Fusarium oxysporum f.sp. Lycopersici isolates 7 and 9 under laboratory conditions.

\begin{tabular}{|c|c|c|c|c|c|}
\hline \multirow{2}{*}{ Treatment } & \multirow{2}{*}{ concentration $\%$} & \multicolumn{4}{|c|}{ Av. growth of F.oxysporum f.sp lycopersici (mm) } \\
\hline & & $\begin{array}{c}\text { isolate } 7 \\
(\mathrm{~mm})\end{array}$ & reduction\% & $\begin{array}{c}\text { isolate } 9 \\
(\mathrm{~mm})\end{array}$ & reduction $\%$ \\
\hline \multirow{3}{*}{$\begin{array}{c}\text { African } \\
\text { milk bush }\end{array}$} & 5 & 63.13 & 29.86 & 64.70 & 28.11 \\
\hline & 10 & 56.61 & 37.10 & 58.00 & 35.56 \\
\hline & 20 & 50.74 & 43.62 & 52.00 & 42.22 \\
\hline \multirow{3}{*}{ Aloe vera } & 5 & 71.03 & 21.08 & 72.30 & 19.67 \\
\hline & 10 & 66.60 & 26.00 & 66.70 & 25.89 \\
\hline & 20 & 59.47 & 33.92 & 61.00 & 32.22 \\
\hline \multirow{3}{*}{$\begin{array}{c}\text { Camphor } \\
\text { trees }\end{array}$} & 5 & 49.39 & 45.12 & 50.70 & 43.67 \\
\hline & 10 & 47.56 & 47.16 & 47.00 & 47.78 \\
\hline & 20 & 44.85 & 50.17 & 46.00 & 48.89 \\
\hline \multirow{3}{*}{ Mint } & 5 & 60.79 & 32.46 & 62.70 & 30.33 \\
\hline & 10 & 52.39 & 41.79 & 54.30 & 39.67 \\
\hline & 20 & 46.86 & 47.93 & 47.00 & 47.78 \\
\hline \multirow{3}{*}{ Nerium } & 5 & 68.68 & 23.69 & 67.70 & 24.78 \\
\hline & 10 & 43.59 & 51.57 & 43.70 & 51.44 \\
\hline & 20 & 36.00 & 60.00 & 37.00 & 58.89 \\
\hline \multirow{3}{*}{$\begin{array}{l}\text { prickly } \\
\text { pear }\end{array}$} & 5 & 66.53 & 26.08 & 67.70 & 24.78 \\
\hline & 10 & 59.24 & 34.18 & 60.30 & 33.00 \\
\hline & 20 & 57.01 & 36.66 & 58.00 & 35.56 \\
\hline Control & - & 87.66 & - & 86.65 & - \\
\hline LSD at $5 \%$ & - & 16.49 & - & 5.41 & - \\
\hline
\end{tabular}

\section{Effect of different fungicides on the} fungal growth:

Results shown in Table (7) clear that all the tested fungicides at all used concentrations reduced the growth of Fusarium oxysporum f.sp. Lycopersici. Prevecure energy and Tachigaren fungicides $(20 \%$ conc. $)$ inhibited the growth of both isolates completely. Increasing tne concentration of any tested fungicide caused significant reduction of the growth of either isolate (7) and/or isolate (9) of F.oxysporum lycopersici. On the other hand, the least effective fungicide was Topsin-M followed by Carbendazim. 
Table (7): Effect of some fungicides agents on growth of Fusarium oxysporum f.sp. Lycopersici isolate 7 and 9 under laboratory conditions.

\begin{tabular}{|c|c|c|c|c|c|}
\hline \multirow{2}{*}{ fungicide } & \multirow{2}{*}{ concentration $\%$} & \multicolumn{4}{|c|}{ Av. growth of F.oxysporum lycopersici (mm) } \\
\hline & & isolate 7 & reduction $\%$ & isolate 9 & reduction $\%$ \\
\hline \multirow{3}{*}{ Carbendazim } & 50 & 24.38 & 72.91 & 24.30 & 73.00 \\
\hline & 100 & 17.25 & 80.83 & 18.70 & 79.22 \\
\hline & 200 & 6.84 & 92.40 & 6.00 & 93.33 \\
\hline \multirow{3}{*}{$\begin{array}{l}\text { Previcur } \\
\text { energy }\end{array}$} & 50 & 16.83 & 81.30 & 17.70 & 80.33 \\
\hline & 100 & 9.02 & 89.98 & 8.00 & 91.11 \\
\hline & 200 & 0.70 & 99.22 & 0.00 & 100.00 \\
\hline \multirow{3}{*}{ Rizolex - T } & 50 & 26.44 & 70.62 & 28.00 & 68.89 \\
\hline & 100 & 20.21 & 77.54 & 22.30 & 75.22 \\
\hline & 200 & 7.93 & 91.19 & 7.70 & 91.44 \\
\hline \multirow{3}{*}{ Tachigaren } & 50 & 1.94 & 97.84 & 2.00 & 97.78 \\
\hline & 100 & 0.69 & 99.23 & 0.30 & 99.67 \\
\hline & 200 & 0.00 & 100.00 & 0.00 & 100.00 \\
\hline \multirow{3}{*}{ Topsin-M } & 50 & 28.80 & 68.00 & 29.30 & 67.44 \\
\hline & 100 & 16.58 & 81.58 & 17.70 & 80.33 \\
\hline & 200 & 6.95 & 92.28 & 8.30 & 90.78 \\
\hline Control & & 87.66 & & 86.65 & 3.72 \\
\hline LSD at $5 \%$ & & 2.00 & & 4.11 & \\
\hline
\end{tabular}

\section{Effect of some plant extracts under greenhouse conditions:}

Results present in Table (8) Indicate that application of aloe vera plant extract had the most efficiency for improving the vegetative growth of the most susceptible Elissa tomato cultivar. Such extract increased root weight and length, number of leaves and consequently the whole plant weight and length. In the meantime, Aloe vera and Nerium extracts (20\%) showed the best efficiency in decreasing vessels discoloration, both (6.90). such discoloration recorded 14.5, 11.60, 11.3 and 8.10; respectively for comphore, euphorbia, mint and prickly pear at $5 \%$ concertation. In all cases, increasing the concentration of any plant extract led to reduce the vessels discoloration, significantly. However, control (-) plants grown in such infested soil with Fusarium oxysporum f.sp. Lycopersici completely died just after after two weeks from planting. 
Table (8): Effect of different concentrations of some plant extracts agents on the growth average of Elissa tomato cultivar under greenhouse conditions 80 days after transplanting:

\begin{tabular}{|c|c|c|c|c|c|c|c|c|c|c|}
\hline \multirow[b]{2}{*}{ Treatment } & \multirow{2}{*}{$\begin{array}{l}\text { Concentra } \\
\text { tion } \%\end{array}$} & \multicolumn{3}{|c|}{ Root } & \multicolumn{2}{|c|}{ Stem } & \multicolumn{2}{|c|}{ Leaves } & \multicolumn{2}{|c|}{$\begin{array}{l}\text { The whole } \\
\text { plant }\end{array}$} \\
\hline & & $\begin{array}{c}\text { Weight } \\
\text { (gm) }\end{array}$ & $\begin{array}{l}\text { Length } \\
\text { (cm) }\end{array}$ & $\begin{array}{l}\text { Discoloration } \\
(\mathrm{cm})\end{array}$ & $\begin{array}{c}\text { Weight } \\
\text { (gm) }\end{array}$ & $\begin{array}{l}\text { Length } \\
\text { (cm) }\end{array}$ & $\begin{array}{l}\text { weight } \\
\text { (gm) }\end{array}$ & No. & $\begin{array}{c}\text { weight } \\
(\mathrm{gm})\end{array}$ & $\begin{array}{c}\text { length } \\
(\mathrm{cm})\end{array}$ \\
\hline \multirow{3}{*}{$\begin{array}{c}\text { african } \\
\text { milk } \\
\text { bush }\end{array}$} & 50 & 7.80 & 16.90 & 11.60 & 54.39 & 45.70 & 57.59 & 66.00 & 119.78 & 62.60 \\
\hline & 100 & 9.75 & 21.20 & 10.40 & 63.58 & 44.80 & 75.47 & 68.00 & 148.80 & 66.00 \\
\hline & 200 & 10.29 & 22.20 & 8.40 & 69.18 & 51.40 & 81.79 & 71.00 & 161.26 & 73.60 \\
\hline \multirow{3}{*}{ aloe vera } & 50 & 10.93 & 15.60 & 13.50 & 68.46 & 47.30 & 82.53 & 72.00 & 161.92 & 62.90 \\
\hline & 100 & 11.01 & 16.50 & 9.40 & 74.75 & 50.40 & 83.81 & 74.00 & 169.57 & 66.90 \\
\hline & 200 & 11.44 & 21.80 & 6.90 & 75.78 & 58.50 & 84.77 & 81.00 & 171.99 & 80.30 \\
\hline \multirow{3}{*}{ Camphor } & 50 & 6.31 & 17.40 & 14.50 & 51.66 & 46.60 & 69.44 & 82.00 & 127.41 & 64.00 \\
\hline & 100 & 11.28 & 20.90 & 11.50 & 71.41 & 52.70 & 88.44 & 84.00 & 171.13 & 73.60 \\
\hline & 200 & 13.76 & 21.70 & 11.00 & 84.35 & 53.00 & 93.84 & 85.00 & 191.95 & 74.70 \\
\hline \multirow{3}{*}{ Mint } & 50 & 7.91 & 15.80 & 11.30 & 51.83 & 51.40 & 58.74 & 70.00 & 118.48 & 67.20 \\
\hline & 100 & 8.18 & 18.70 & 10.30 & 53.82 & 47.90 & 66.48 & 76.00 & 128.48 & 66.60 \\
\hline & 200 & 9.94 & 21.60 & 9.30 & 57.44 & 50.90 & 72.10 & 81.00 & 139.48 & 72.50 \\
\hline \multirow{3}{*}{ Nerium } & 50 & 6.65 & 13.20 & 9.40 & 43.67 & 36.80 & 49.62 & 66.00 & 99.94 & 50.00 \\
\hline & 100 & 8.22 & 14.80 & 7.30 & 56.71 & 52.10 & 61.66 & 69.00 & 126.59 & 66.90 \\
\hline & 200 & 8.76 & 17.20 & 6.90 & 57.97 & 50.40 & 67.01 & 73.00 & 133.74 & 67.60 \\
\hline \multirow{3}{*}{$\begin{array}{l}\text { prickly } \\
\text { pear }\end{array}$} & 50 & 5.67 & 10.50 & 8.10 & 39.67 & 37.90 & 45.97 & 63.00 & 91.31 & 48.40 \\
\hline & 100 & 6.90 & 12.10 & 7.80 & 43.53 & 45.60 & 53.36 & 68.00 & 103.79 & 57.70 \\
\hline & 200 & 8.08 & 13.00 & 7.20 & 54.91 & 43.60 & 68.46 & 77.00 & 131.45 & 56.60 \\
\hline \multicolumn{2}{|c|}{ control (-) } & 20.32 & 26.70 & 0.00 & 139.81 & 88.70 & 163.43 & 104.00 & 323.56 & 115.40 \\
\hline $\begin{array}{c}\text { LSD at } \\
5 \%\end{array}$ & & 0.30 & 0.75 & 0.84 & 5.52 & 4.53 & 7.20 & 5.24 & 13.03 & 7.55 \\
\hline
\end{tabular}

\section{Effect of some fungicides under greenhouse conditions:}

Results given in Table (9) clear that Previcur energy was the best tested fungicide against the infection with tomato wilt pathogen. Such fungicide at the concentration of $50 \%$ significantly improved root stem length and weight and increased the number and weight of leaves / plants. On the other hand, browning of root vessils
Gave the minimum values when this fungicide was applied (Table 9). Carbendazim fungicide came in the second rank and Topson-M was the least effective fungicide in controlling tomato wilt disease. Increasing the concentration of all tested fungicides $\quad(50-200 \%)$ showed significant effect both in reducing the plant growth parameters. 
Table (9): Effect of some fungicides on the growth average of Elissa tomato cultivar under greenhouse condition $\mathbf{8 0}$ days after transplanting.

\begin{tabular}{|c|c|c|c|c|c|c|c|c|c|c|}
\hline \multirow[b]{2}{*}{ Treatment } & \multirow{2}{*}{$\begin{array}{c}\text { Concen } \\
\text { tration } \\
\%\end{array}$} & \multicolumn{3}{|c|}{ Root } & \multicolumn{2}{|c|}{ Stem } & \multicolumn{2}{|c|}{ Leaves } & \multicolumn{2}{|c|}{ The hole plant } \\
\hline & & $\begin{array}{c}\text { weight } \\
\text { (gm) }\end{array}$ & $\begin{array}{l}\text { length } \\
(\mathrm{cm})\end{array}$ & $\begin{array}{c}\text { Discolo } \\
\text {-ration } \\
(\mathrm{cm})\end{array}$ & $\begin{array}{c}\text { weight } \\
\text { (gm) }\end{array}$ & $\begin{array}{l}\text { length } \\
(\mathrm{cm})\end{array}$ & $\begin{array}{c}\text { weight } \\
\text { (gm) }\end{array}$ & No. & $\begin{array}{c}\text { weight } \\
\text { (gm) }\end{array}$ & $\begin{array}{c}\text { length } \\
(\mathrm{cm})\end{array}$ \\
\hline \multirow{3}{*}{ Carbendazim } & 50 & 17.18 & 20.6 & 2.8 & 109.84 & 68 & 124.36 & 71 & 251.38 & 88.6 \\
\hline & 100 & 18.24 & 22.4 & 0 & 126.13 & 86.5 & 137.98 & 88 & 282.35 & 108.9 \\
\hline & 200 & 20.06 & 24.5 & 0 & 132.18 & 83.3 & 167.52 & 92 & 319.76 & 107.8 \\
\hline \multirow{3}{*}{$\begin{array}{l}\text { Previcur } \\
\text { energy }\end{array}$} & 50 & 19.66 & 21.4 & 1 & 127.73 & 71 & 155 & 70 & 302.39 & 92.4 \\
\hline & 100 & 20.18 & 23.4 & 0 & 135.19 & 87.1 & 164.43 & 91 & 319.8 & 110.5 \\
\hline & 200 & 20.26 & 24.6 & 0 & 136.75 & 87.7 & 154.75 & 101 & 311.76 & 112.3 \\
\hline \multirow{3}{*}{ Rizolex - T } & 50 & 15.19 & 18.4 & 2.8 & 97.07 & 37 & 118.67 & 71 & 230.93 & 55.4 \\
\hline & 100 & 16.39 & 20.4 & 2.3 & 108.45 & 49.4 & 125.62 & 73 & 250.46 & 69.8 \\
\hline & 200 & 19.26 & 21.2 & 1.8 & 123.88 & 57.3 & 147.95 & 79 & 291.09 & 78.5 \\
\hline \multirow{3}{*}{ Tachigaren } & 50 & 14.11 & 19.3 & 3.1 & 91.08 & 43.7 & 109.44 & 69 & 214.63 & 63 \\
\hline & 100 & 17.87 & 21.2 & 2.4 & 109.2 & 51.6 & 125.14 & 82 & 252.21 & 72.8 \\
\hline & 200 & 19.96 & 22.5 & 0.7 & 124.7 & 66.1 & 139.02 & 88 & 283.68 & 88.6 \\
\hline \multirow{3}{*}{ Topsin-M } & 50 & 14.11 & 15.5 & 4.6 & 95.89 & 45.3 & 118.19 & 63 & 228.19 & 60.8 \\
\hline & 100 & 15.87 & 18.4 & 2.9 & 107.65 & 65.8 & 125.08 & 68 & 248.6 & 84.2 \\
\hline & 200 & 18.09 & 19.4 & 1.3 & 129.12 & 67.1 & 151.43 & 75 & 298.64 & 86.5 \\
\hline \multicolumn{2}{|c|}{ control (-) } & 20.32 & 26.7 & 0 & 139.81 & 88.7 & 163.43 & 104 & 323.56 & 115.4 \\
\hline LSD at $5 \%$ & & 1.2 & 1.49 & 0.28 & 10.65 & 5.26 & 15.25 & 5.99 & 21.52 & 6.41 \\
\hline
\end{tabular}

\section{DISCUSSION}

Fusarium oxysporum f. sp. lycopersici (FOL) (Sacc.) W.C. Snyder and H. N. Hans was isolated from 10 collected samples from different districts of 6 Egyptian governorates. The highly percentages of the fungal isolates were obtained from Sadat city (Menoufia governorate) followed by El-salhia district (Shaqia governorate).
However, the least frequency of this fungus was achieved from Alexandria and Aswan governorates. Such results could be due to different environmental conditions and/or crop rotation of the examined fields were deprives of salanaceae plants encourage the persistence and reproduction the pathogen (Ammar, 2003) . 
Fusarium oxysporum f.sp. lycopersici was also identified as the causal organis of tomato wilt disease by ( Srivastava and Singh (2015), Anita et al. (2016), Ghazalibiglar et al. (2016), Onaran, and Bayan (2016), Akhtar et al. (2017), Raza et al. (2017) and Suneeta et al. (2017).

Pathogenicity test experiments showed that isolate (7) and (9) were the most aggressive ones while isolates 1,6 and 8 showed less aggressiveness. This could be due to genetic structure of different isolates which affect toxins secretion (Ammar, 2003).

Perevcure energy and tachigren fungicides (20\%) concentration completely inhibited the growth of both pathogenic isolates. increasing the concentration of any tested fungicide showed more efficiency in reducing the fungal growth. Such results are of logic and were also observed by (Sandroni and Navarro (2002), Satish et al (2009), Javaid and Bashir (2015), Djekoun et al. (2016), Jat et al. (2017), Onaran, and Bayan (2016), Yadav and Ansari (2016), Dianyu et al. (2017), Suneeta et al. (2017), Petkar et al. (2017), Praful and Nandakishor (2017), Wavare et al. (2017), Hussein (2018), Bashir et al. (2018), Waghmare et al. (2018) and XiaoMei et al. (2019).

Under greenhouse and arterial soil conditions infestation (isolate 9) Brivio tomato cultivar showed the least susceptibility to wilt disease while, Elissa cv. was the most susceptible one. It is well known that cultivating the resistant cultivars is the best control method of any pathogen, where no other control treatment would be apply. So, breeding for less susceptible tomato cultivars to Fusarium oxysporum f. sp. Lycopersici is the successive way to minimize the losses due to this fungus.

Alo Vera and nirium plant water extracts were the most effective ones for reducing wilt disease and improving the plant growth, under greenhouse and artificial soil infestation conditions. This was reported by (Srivastava and Singh (2015), Anita et al. (2016), Ghazalibiglar et al. (2016), Onaran and Bayan (2016), Akhtar et al. (2017), Raza et al. (2017) and Suneeta et al. (2017).

$\begin{gathered}\text { As a stander control method, } \\ \text { and tachigren }\end{gathered}$
Perevcure energy $\begin{gathered}\text { and } \\ \text { fungicides were tested and gave the best }\end{gathered}$
results in reducing the disease and
improving the plant growth. Such results
are in agreement with (Sandroni and
Navarro (2002), Satish et al. (2009),
Javaid and Bashir (2015), Djekoun et al.
(2016), Jat et al. (2017), Onaran, and Bayan
(2016), Yadav and Ansari (2016), Dianyu et
al. (2017), Suneeta et al. (2017), Petkar et
al. (2017), Praful and Nandakishor (2017),
Wavare et al. (2017), Hussein (2018),
Bashir et al. (2018), Waghmare et al. (2018)
and XiaoMei et al (2019).

\section{REFERENCE}

Akhtar, T., Q. Shakeel, G. Sarwar, S. Muhammad, Y. Iftikhar, M. I. Ullah and A. Hannan (2017). Evaluation of fungicides and biopesticides for the control of fusarium wiltof tomato. Pak. J. Bot, 49(2): 769-774.

Angelo, G. (1995). Soil-borne pathogens in greenhouse crops and their control. 119 in integrated pest and disease management in protected crops 19-30 June (1995) with the collaboration of: International organization for biological and integrated control of onxious animal and plants (IOBS)., volume II.

Barnett, H. J. (1960). Illustrated. Genera of imperfect fungi. Burgess Minneapolis. USA, 225 pp.

Barnett, H. L. and B. B. Hunter (1998). Illustrated Genera of Imperfect Fungi, 4th edition. APS Press, St. Paul, Burgress Publishing Company, Minneapolis MN, P. 241. 
Bashir, M. R., M. Atiq, M. Sajid, M. Mohsan, W. Abbas, M. W. Alam and M. Bashair (2018). Antifungal exploitation of fungicides against Fusarium oxysporum f. sp. capsici causing Fusarium wilt of chilli pepper in Pakistan. Environmental Science and Pollution Research, 25 (7) :6797-6801.

Booth, C. (1971). The genus Fusarium. CM1, Kew, Surray, England, 237 pp.

Chehri, K. (2016). Molecular identification of pathogenic Fusarium species, the causal agents of tomato wilt in western Iran. Journal of Plant Protection Research, 56: 143-148.

Datnoff, L. E., S. Nemec and K. Pohronezny (1993). Biological control of Fusariumcrown and root rot of tomato. Phytopathology, 83: 14061407.

Dianyu, W., T. Minghao, L. Hongpeng and L. Xiangguo (2017). Antifungal Activities of Eight Fungicides against Fusarium oxysporum Schlecht. Plant Diseases and Pests, 8 (5): 30-32.

Djekoun, M., H. Berrebbah, A. Saib and M. R. Djebar (2016). Determination of Median Effective Inhibitory Concentration of Three Fungicides Widely Used for Treatment of Wheat on the Target Pest Fusarium sp. Environmental Toxicology, 10 (2): 109-114.

Ghazalibiglar, H., D. R. Kandula and J. G. Hampton (2016). Biological control of fusarium wilt of tomato by Trichoderma isolates.

Gilman, J.C. (1957). A manual of soil fungi. Second Edition. The lowa State University Press. lowa. USA, 450 pp.

Hussein, S. N. (2019). Integrated management of the Fusarium vascular wilt disease of Cucurbita pepo in Iraq. Journal of Agricultural and Marine Sciences [JAMS], 23 (1): 40-47.
Ibrahim, I.A. and M.A. Abd-El-Rehim (1965). Fusarium root rot and wilt on horse-bean (Visia faba var-equine) Alex. J. Agric. Res., 13: 415-426.

Jat, M. K., R. R. Ahir and G. L. Kakraliya (2017). Evaluation of fungicides as seed treatment against coriander wilt disease caused by Fusarium oxysporum f. sp. corianderii. International Journal of Plant Protection, 10 (1): 92-95.

Javaid, A. and A. Bashir (2015). Radish extracts as natural fungicides for management of Fusarium oxysporum f. sp. lycopersici, the cause of tomato wilt. Pak. J. Bot, 47: 321-324.

Joseph, A. (1994). Emerging technologies for the control of post- harvest diseases of fresh fruit and vegetables, p.1-10 in biological control of postharvest diseases theory and practice. Charles L. Wilson and Michael, E. Wisniewski (Eds.) by CRC, Press, pp.182

Manikandan, R., S. Harish, G. Karthikeyan and T. Raguchander (2018). Comparative proteomic analysis of different isolates of Fusarium oxysporum f. sp. lycopersici to exploit the differentially expressed proteins responsible for virulence on tomato plants. Frontiers in microbiology, 9, 420.

Mutwally, H. M. A., M. A. Omar and M. Bedaiwy (2002). Microsporum gallinae growth response to some plant extracts. Faculty of Applied Science, Umm Al-Qura University, Makkah, Kingdom of Saudi Arabia, 1-8.

Nelson, P.E., T.A. Toussoun and W.F.O. Marasas (1983). Fusarium species: Anillustrated manual for identification. Pennsylvania State University Press, University Park.

Onaran, A., \& Bayan, Y. (2016). Antifungal activity of Liquidambar orientalis $L$., 
and Myrtus communis L. against some plant pathogenic fungi. Scientific Papers. Series A. Agronomy, 59: 360364.

Petkar, A., D. B. Langston, J. W. Buck, K. L. Stevenson and P. Ji (2017). Sensitivity of Fusarium oxysporum $f$. sp. niveum to prothioconazole and thiophanate-methyl and gene mutation conferring resistance to thiophanatemethyl. Plant disease, 101(2): 366-371.

Praful, K. and H. V. Nandakishor (2017). Fungicides combination for management of chickpea wilt incited by Fusarium oxysporum f. sp. ciceri. Journal of Mycopathological Research, 55(1): 93-99.

Raza, W., N. Ling, R. Zhang, Q. Huang, Y. $X u$ and $Q$. Shen (2017). Success evaluation of the biological control of Fusarium wilts of cucumber, banana, and tomato since 2000 and future research strategies. Critical reviews in biotechnology, 37(2): 202-212.

Sandroni, D. and J. Navarro (2002). Hymexazol. Intrinsic characteristics and efficacy in controlling fungi responsible of dumping-off disease on sugar beet with seed dressing [Beta vulgaris L.-Emilia-Romagna]. Atti delle Giornate Fitopatologiche (Italy).

Satish, S., M. P. Raghavendra and K. A. Raveesha (2009). Antifungal potentiality of some plant extracts against Fusarium sp. Archives of Phytopathology and Plant Protection, 42(7), 618-625.
Srivastava, N. and M. Singh (2015). Ecofriendly management of disease complex of tomato caused by root knot nematode and wilt causing fungus. Environment Conservation Journal, 16 (1\&2): 113-116.

Suneeta, P., S. V. Kumar, K. E. A. Aiyanathan and S. Nakkeeran (2017). Promissory Action of Trichoderma spp. and Fungicides in the Management of Fusarium Wilt of Gerbera. Journal of Pure and Applied Microbiology, 11(1): 241-247.

Tsair-Bor, Y. and C. Shang-Tzen (2008). Synergistic effects of cinnamaldehyde in combination with eugenol against wood decay fungi. Bioresource Technology. 99: 232-236.

Waghmare, S. J., P. D. Mahajan, B. B. Chirame and V. V. Datar (2018). In vitro efficacy of fungitoxicants on the growth of Fusarium oxysporum f. sp. carthami isolates causing wilt of safflower. International Journal of Plant Protection, 11(1): 39-45.

Wavare, S. H., R. M. Gade and A. V. Shitole (2017). Antifungal efficacy of floral extracts, biocontrol agents and fungicides against Fusarium oxysporum f. sp. ciceri. Indian Phytopathology, 70(2): 191-199.

Yadav, S. and M. M. Ansari (2017). Isolation, Identification and In vitro Evaluation of Fungicides against Fusarium Leaf Blight of Soybean Caused by F. oxysporum. Soybean Research, 46. 


\section{تأثير بعض المستخلصات النباتية والمبيدات على الإصابة بمرض الأبول الفيوزارمهى فى بعض أصناف الطماطم}
محمد محمد عمار، حسام محمد عوض، محمود مسعد محمود سالم جاب الله

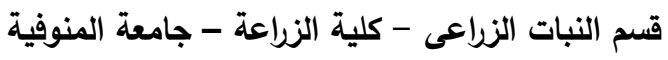

\section{الملخص العربي}

يعتبر مرض الذبول الفيوزارمى لنباتات الطماطم من الأمراض الخطيرة التى تؤثر على نمو وإنتاج المحصول وقد أجريت

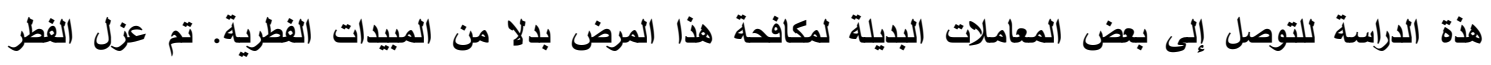
Fusarium oxysporum f.sp. lycopersici المنوفية والثرقية) وكانت نسبة تواجد المرض فى هذة المحافظات تتراوح بين (42 - 25) على التوالى فى محافظتى

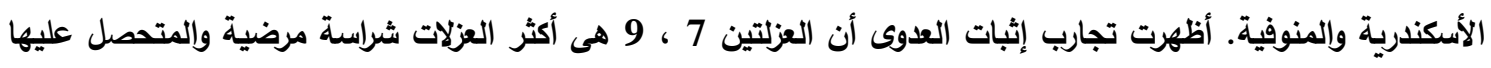

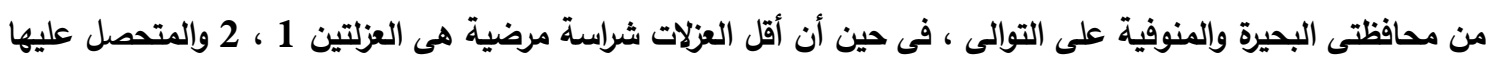

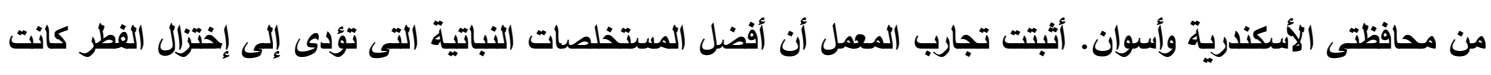

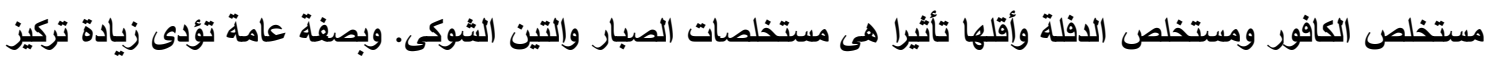

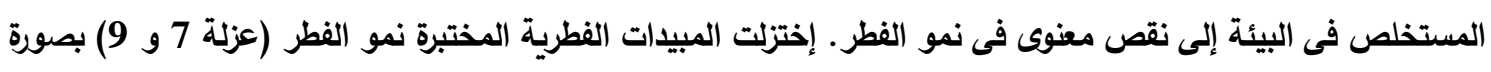

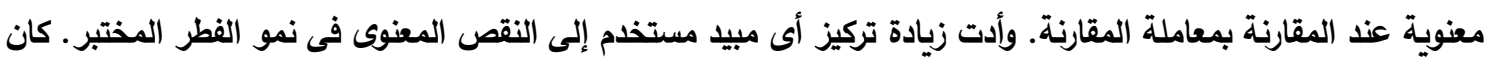

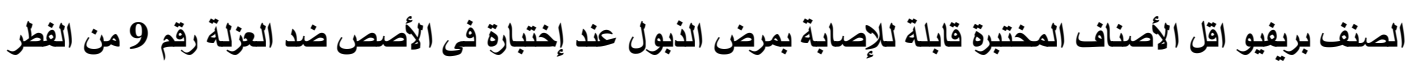
Fusarium oxysporum f.Sp. Iycopersici

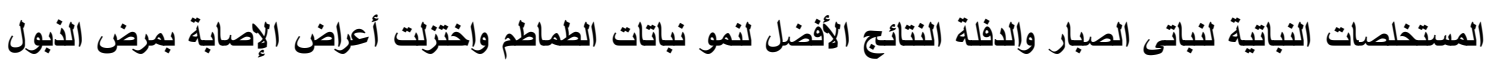

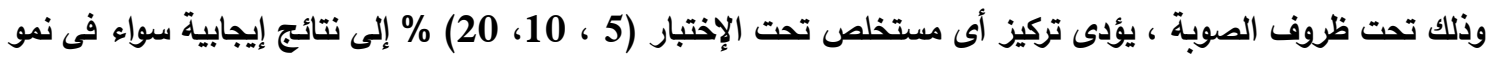

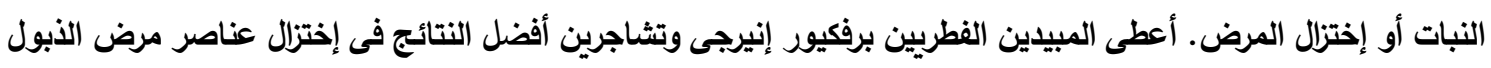
وتحسين نمو نباتات الطماطم صنف إليسا. 
M. Ammar, et al., 
M. Ammar, et al., 